\title{
The age of the Nodular Limestone Formation (Late Cretaceous), Narmada Basin, central India
}

\author{
Susheel Kumar, Deo Brat PathaK*, Bindhyachal Pandey, \\ Anand Kumar Jaitly, and Jai Prakash Gautam \\ Department of Geology, Stratigraphy and Invertebrate Palaeontology Laboratory, Center of Advanced Study, \\ Banaras Hindu University, Varanasi 221 005, India. \\ *Corresponding author.e-mail: dbpathak@yahoo.com
}

MS received 8 September 2017; revised 10 February 2018; accepted 21 February 2018; published online 29 September 2018

The age of the marine Nodular Limestone Formation of the Bagh Group is refined at Substage level through ammonoid and inoceramid index taxa. The study is based on the fresh collections from three welldefined successive intervals (Lower Karondia, Upper Karondia and Chirakhan members) of this formation having excellent exposures in different localities of the Narmada Basin, central India. The first record of the widely distributed Turonian ammonoid genera Spathites Kummel and Decker and Collignoniceras Breistroffer from the Nodular Limestone Formation constrained its age exclusively to Turonian. The Early Turonian species Spathites (Jeanrogericeras) aff. revelieranus (Courtiller) and Mytiloides labiatus (Sclotheim) occur in the lower part, while the Middle Turonian marker Collignoniceras cf. carolinum (d'Obrbigny) and Inoceramus hobetsensis (Nagao and Matsumoto) occurs in the upper part of the Karondia Member. The record of the index species Inoceramus teshioensis (Nagao and Matsumoto) in association with Placenticeras mintoi Vredenburg from Chirakhan Member allows a definite Late Turonian age. The present contribution is an attempt to resolve the controversies in the age of the Nodular Limestone Formation and also demarcation of the three divisions (Early, Middle and Late) of the Turonian Stage in the Narmada Basin, central India.

Keywords. Nodular Limestone Formation; ammonoids; inoceramid bivalves; Turonian; Narmada Basin.

\section{Introduction}

Narmada Basin is an intracratonic rift basin confined to a narrow ENE-WSW trending graben (Biswas 1987; Acharya and Lahiri 1991; Tripathi 2006). It is bounded by a series of sub-parallel strike-slip faults forming the Narmada-Son lineament and originated due to the reactivation of fault during the Early Cretaceous along the NarmadaSon lineament with regional uplift to the north and south forming an intervening graben (Kumar et al. 1999; Racey et al. 2016). The termination of
Cretaceous sedimentation in the Narmada Basin is most probably due to the uplift of the Saurastra Arch (horst) to the NW (Biswas 1987).

The Cretaceous sedimentary successions in the Narmada Basin occur as isolated outcrops over Precambrian crystalline (granites/metamorphic) basement and overlain by Deccan basalts in the central and western peninsular regions of India (Tripathi 2006; Racey et al. 2016). These sedimentary records were initially designated as 'Bagh Beds' by Blanford (1869) with four lithounits, later formally named by Bose (1884) as Nimar 
Table 1. Lithostratigraphic framework of marine sedimentary succession in the Narmada Basin, central India (after Jaitly and Ajane 2013).

\begin{tabular}{llll}
\hline \multicolumn{3}{c}{ Lameta Group and Deccan Traps } \\
\hline Group & Formation & Member & \multicolumn{1}{c}{ Age } \\
\hline Bagh & Coralline Limestone & & Coniacian \\
& Nodular Limestone & Chirakhan & $\begin{array}{l}\text { Late Turonian } \\
\text { Middle Turonian }\end{array}$ \\
& & Karondia & Marly Turonian \\
& Nimar Sandstone & & Cenomanian \\
Crystallin rocks & & \\
\hline
\end{tabular}

Sandstone, Nodular Limestone, Deola-Chirakhan Marl and Coralline Limestone in the ascending order. The lithostratigraphic scheme of Bose (1884) is considered as the basic classification which has been consistently subjected to various modifications by subsequent workers. Further, 'Bagh Beds' was renamed as Bagh Group by Akhtar and Khan (1997) along with its further subdivisions into four formations (Nimar Sandstone, Nodular limestone, Deola-Chirakhan and Corralline Limestone formations in the ascending order). The recent lithostratigraphic scheme of Jaitly and Ajane (2013) appears to be more persuasive and is followed in the present work (table 1).

Several stratigraphic sections of the Bagh Group are investigated in different localities (Sitapuri, Rampura, Bagh Cave, Kosdana, Chakrur, Zeerabad, Karondia and Khanwara) of Bagh area (figure 1). However, all the three Nimar Sandstone, Nodular Limestone and Coralline Limestone formations are exposed on the left bank of the Mann River in the west of Sitapuri and near Rampur village. These have yielded all the ammonoids and inoceramids used here for the biostratigraphic purpose.

The age of the Bagh Group, in general, and the Nodular Limestone Formation, in particular, has always been a matter of discussion among the investigators working on the different fossil groups. The present annotations are noteworthy to reach on a definite conclusion and strengthening the assignment of Turonian age to the Nodular Limestone Formation. Also, the elaborated evidences permit us to exactly differentiate the Early, Middle and Late Turonian substages within the Nodular Limestone Formation in the Narmada Basin, central India.

\section{Age of the Nodular Limestone Formation}

Chiplonkar and Ghare (1976), Badve and Ghare (1977) and Chiplonkar et al. (1977) assigned Turonian-Coniacian age to the Nodular Limestone and Coralline Limestone formations on the basis of the presence of various placenticeratid ammonoids. The immediately underlying uppermost part of the Nimar Sanstone Formation has been dated as Late Turonian-Early Coniacian by Jafar (1982) based on nannofossils, while the record of the bryozoans Chiplonkarina dimorphopora Chiplonkar from the same unit suggests an age not older than Upper Cenomanian (Racey et al. 2016) as evident through its known stratigraphic range (Taylor and Badve 1995). Kundal and Sanganwar (1998) identified the diverse calcareous algae assemblages from the uppermost part of the Nimar Sandstone and suggested a Cenomanian-Turonian age. Bardhan et al. (2002) recorded ammonite Placenticeras kaffrarium Etheridge and inoceramid Voliceramus involutus (Sowerby), respectively from the middle and uppermost parts of the Nodular Limestone Formation and concluded that the Nodular Limestone Formation is of Early to Middle Coniacian age. Khosla et al. (2003), while recording dinosaur bones from the Nimar Sandstone Formation, reviewed earlier classifications of the Bagh Group and suggested CenomanianTuronian age. Later on, Kennedy et al. (2003) recorded the Late Turonian marker ammonite Prionocyclus germari Reuss in the upper Nodular Limestone (?Chirakhan Member) in the Hatani River near Kukshi, and concluded that the previous ammonites and inoceramids records were compatible with a Late Turonian age. He also recorded ammonite fauna $P$. kaffrarium (synonym 


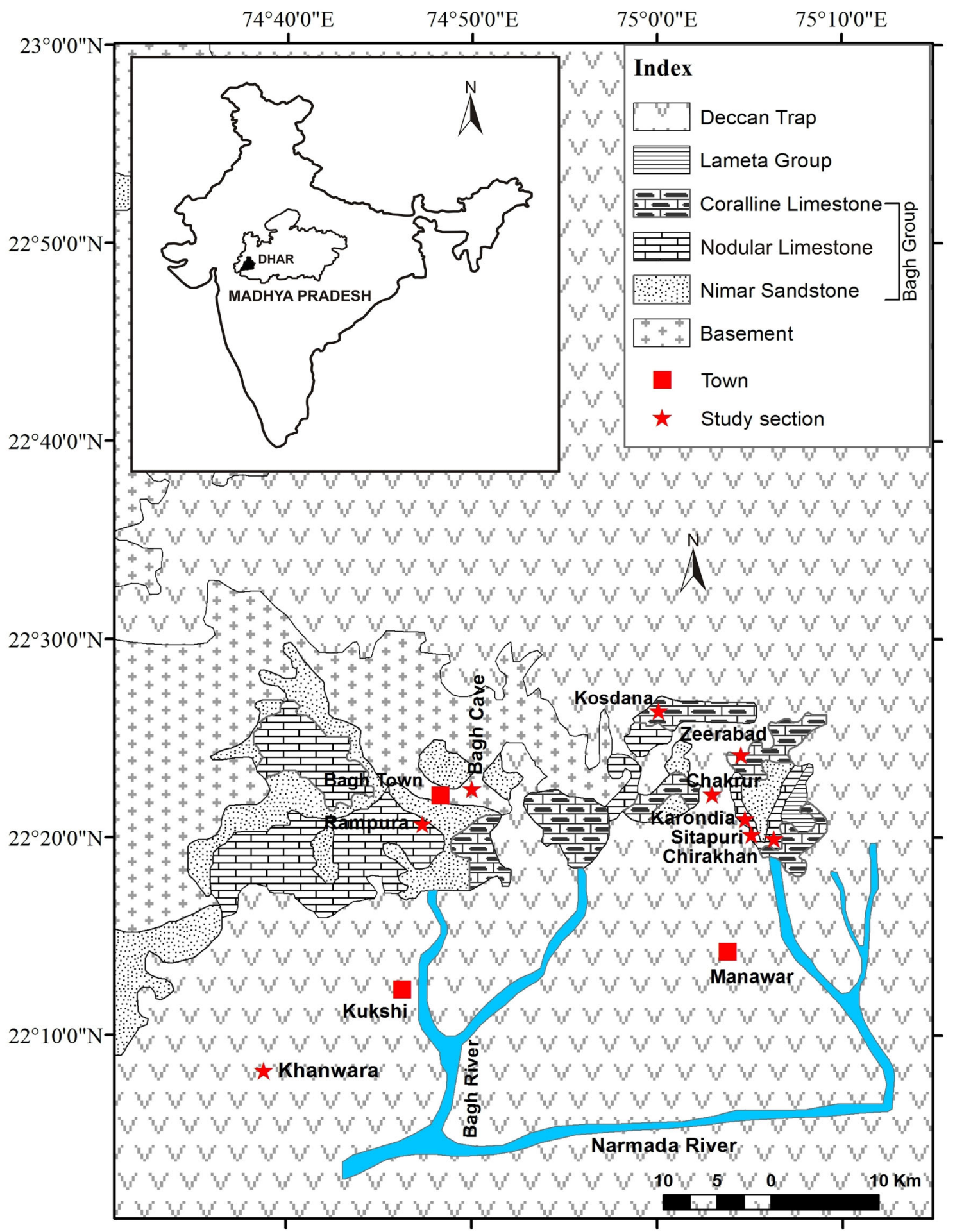

Figure 1. Geological map of the Bagh area, Dhar district, Madhya Pradesh (modified after Jaitly and Ajane 2013).

of Placenticeras mintoi (Vredenburg)) and Parastantonoceras Collignon from the same unit in other part of the basin supporting Turonian age. Further, Kennedy et al. (2003) mentioned a late Middle-early Late Turonian age for an inoceramid fauna from the lower part of the Nodular Limestone Formation (without listing the fauna). An Upper Turonian age to the uppermost part of the Nodular Limestone has been also suggested by Smith (2010) on the basis of the echinoderms. He identified Euporophyma lefebvrei Gauthier (a taxon restricted to the Turonian in Egypt), Micraster mutabilis Lambert, Leptosalenia keatingei Fourtau and Hemiaster integer Lambert 


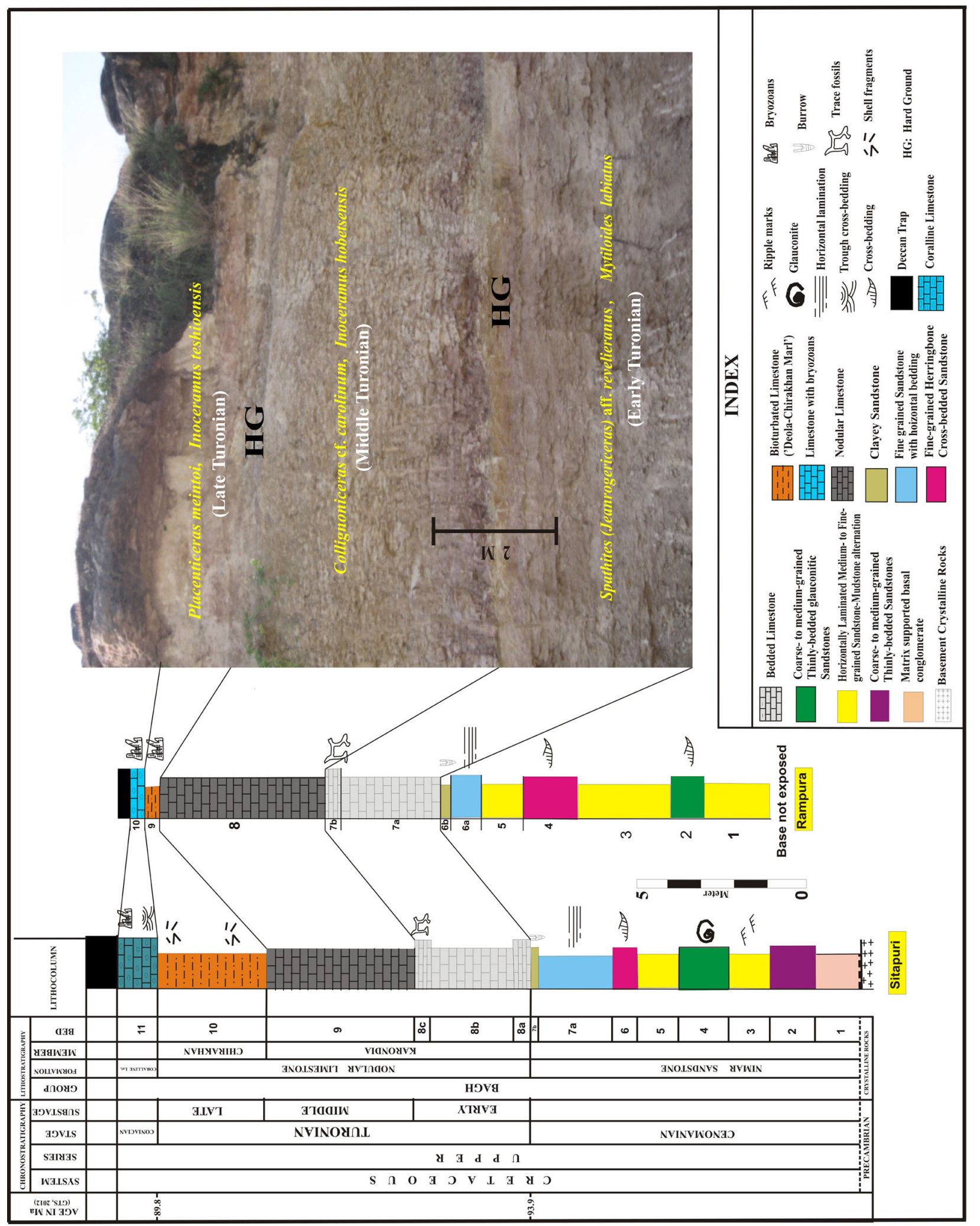

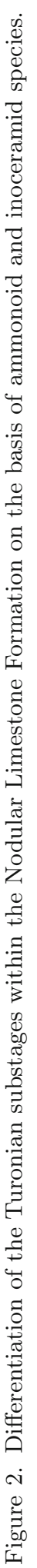


a
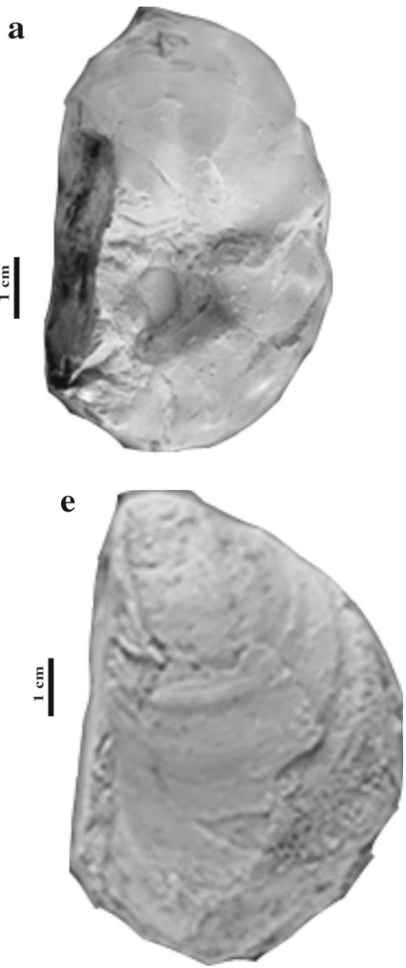

$\mathbf{k}$

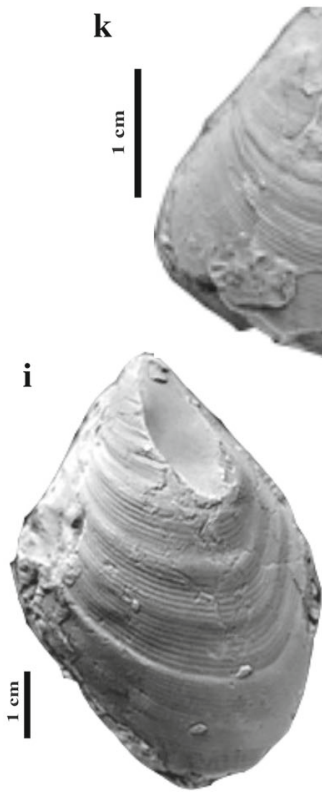

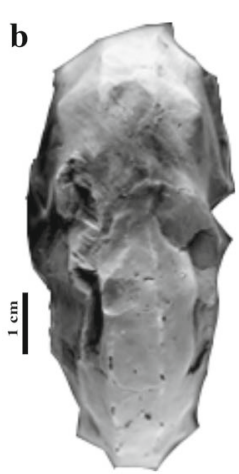

b

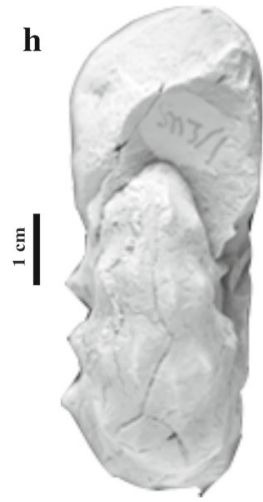

d

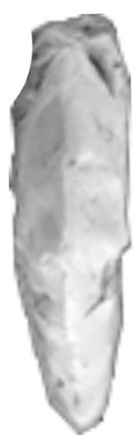

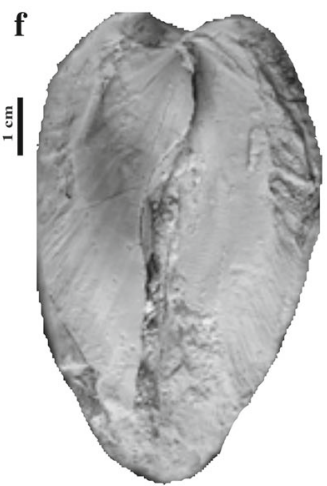
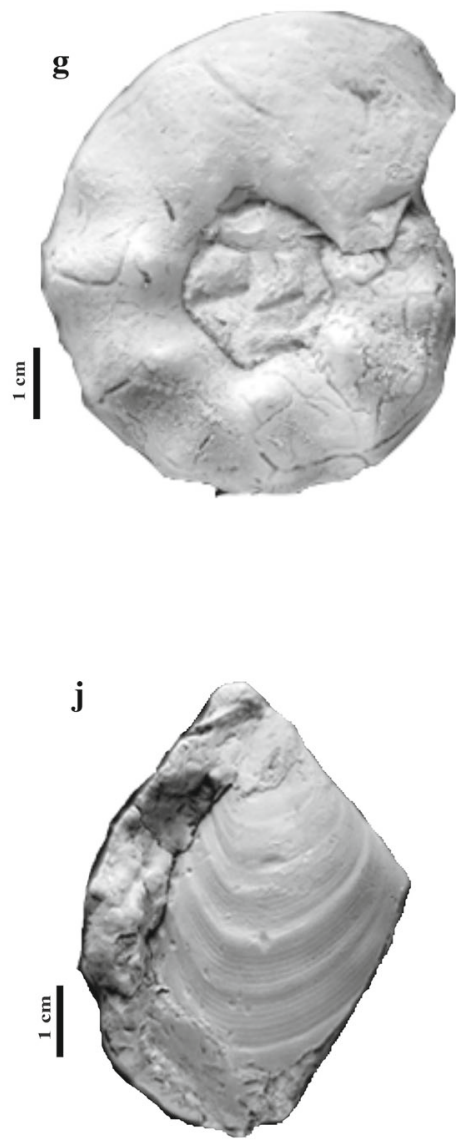

Figure 3. (a and b) Spathites (Jeanrogericeras) aff. revelieranus (Courtiller 1860), (BHU 2014/Sn1/1), (a) lateral view, (b) ventral view, lower part of the Karondia Member, Nodular Limestone Formation, Sitapuri, Narmada Basin, central India, Early Turonian. (c and d) Collignoniceras cf. carolinum (d'obrbigny 1841), (BHU2014/Sn 3/10), (c) lateral view, (d) ventral view, upper part of the Karondia Member, Nodular Limestone Formation, Sitapuri, Narmada Basin, central India, Middle Turonian. (e and f) I. hobetsensis (Nagao and Matsumoto 1939), (BHU 2014/ Sm 12), (e) external view of left valve, (f) anterior view of both valves, upper part of the Karondia Member, Nodular Limestone Formation, Sitapuri, Narmada Basin, central India, Middle Turonian. (g and h) P. mintoi (Vredenburg 1906), (BHU2014/Sn 3/1), (g) lateral view, (h) apertural view, Chirakhan Member, Nodular Limestone Formation, Sitapuri, Narmada Basin, central India, Late Turonian. (i and j) M. labiatus (Sclotheim 1813), (BHU2014/Rn1/18), (i) external view of left valve, (j) (BHU2014/Rn1/49), external view of left valve, lower part of the Karondia Member, Nodular Limestone Formation, Rampura, Narmada Basin, central India, Early Turonian. (k) I. teshioensis (Nagao and Matsumoto 1939), (BHU2014/Rn1/7), external view of left valve, Chirakhan Member, Nodular Limestone Formation, Rampura, Narmada Basin, central India, Late Turonian. 
(known from the Upper Turonian of Madagascar) suggesting that the Nodular Limestone Formation is of Turonian age. Similarly, on the basis of morphologically highly variable ammonite $P$. mintoi (Vredenberg), Jaitly and Ajane (2013) concluded that the Nodular Limestone Formation is of Turonian age. Recently, Racey et al. (2016) have also assigned a Turonian age to the Nodular Limestone Formation based on the record of the planktonic foraminifera species Praeglobotruncana stephani Gandolfi, ?Helvetoglobotruncana helvetica Bolli and Gavelinella tourainensis Butt.

Globally, ammonoids are widely used for age assignment of the Mesozoic marine sedimentary successions; however, inoceramids and planktonic foraminifers are equally good chronometer especially in the Late Cretaceous. Several ammonoid and inoceramid bivalve specimens have been collected from the three successive intervals within the Nodular Limestone Formation (figure 2). The systematic study of these fauna resulted into the identification of ammonoid genera Spathites Kummel and Decker and Collignoniceras Breistroffer along with the inoceramid species Mytiloides labiatus Sclotheim, Inoceramus hobetsensis Nagao and Matsumoto, Inoceramus teshioensis Nagao and Matsumoto, etc., known to be restricted within the Turonian (Nagao and Matsumoto 1939; Wright et al. 1996; Zonova and Yazykova 1998).

The detailed review of the earlier works elaborated above and study of the freshly collected ammonoids and inoceramids, the age of the Nodular Limestone Formation can be safely assigned to Turonian. In the present work, the substage level differentiation of the Turonian has been made for the first time in the Narmada Basin (figure 2).

\subsection{Early Turonian}

The ammonoid species Spathites (Jeanrogericeras) aff. revelieranus (Courtiller) (figure $3 \mathrm{a}$ and b) has been collected from Bed No. 8a at Sitapuri of the lower part of Karondia Member (figure 2). The subgenus Jeanrogericeras itself is known to be restricted within the Early Turonian (Wright et al. 1996), while its species Spathites (Jeanrogericeras) revelieranus (Courtiller) has been recorded from Early Turonian (Mammites nodosoides Zone) of southern Europe (Wilmsen and Nagm 2013). M. labiatus (Sclotheim) (figure $3 \mathrm{i}$ and $\mathrm{j}$ ) collected from the same lithounit at Rampura (Bed No. 7a, figure 2) also represents the Early Turonian interval (Zonova and Yazykova 1998). However, the authors failed to find any evidence of the earliest Turonian Watinoceras coloradoense Zone in the basal most part of the Karondia Member.

\subsection{Middle Turonian}

The Collignoniceras cf. carolinum (d'Obrbigny) (figure $3 \mathrm{c}$ and $\mathrm{d}$ ) and I. hobetsensis (Nagao and Matsumoto) (figure 3e and f) have been collected from Bed No. 9 at Sitapuri (figure 2). Collignoniceras carolinum (d'Obrbigny) is so far known only from the Middle Turonian of the Mediterranean region (Ion et al. 2004; Kennedy and Gale 2016), while $I$. hobetsensis appears first and dominates in the Middle Turonian, although it continues up to Late Turonian (Zonova and Yazykova 1998). The presence of these ammonoid and inoceramid index fauna suggest a Middle Turonian age for the upper part of the Karondia Member.

\subsection{Late Turonian}

The Chirakhan Member (also known as 'Deola Marl' or 'Deola-Chirakhan Marl') of the Nodular Limestone Formation has been assigned Late Turonian convincingly by earlier workers (Kennedy et al. 2003; Smith 2010) mainly based on ammonoid and inoceramid index species. The present record of the Late Turonian index species $I$. teshioensis (Nagao and Matsumoto) (figure 3k) from the Bed No. 9 at Rampura (figure 2) in association with the ammonoid species $P$. mintoi (Vredenburg) (figure $3 \mathrm{~g}$ and $\mathrm{h}$ ) from the Bed No. 10 at Sitapuri (figure 2) further authenticate its Late Turonian age.

\section{Conclusions}

- The detailed investigation of nearly complete sequence of the Bagh Group has been made particularly near Sitapuri and Rampura localities of the Dhar district, central India which allowed us to differentiate all the three successive lithounits - Nimar Sandstone, Nodular Limestone and Coralline Limestone formations.

- The lower Karondia Member and upper Chirakhan Member are also lithostratigraphically differentiated within Nodular Limestone Formation.

- The taxonomic determination of freshly collected ammonoid and inoceramid fauna (figure 3) from the lower and upper parts of the Karondia Member, as also from the Chirakhan Member, strengthens the Turonian age to the Nodular Limestone Formation. 
- The Turonian Stage has been further differentiated into Lower, Middle and Upper Turonian within the Nodular Limestone Formation based on the index Lower, Middle and Upper Turonian ammonoid and inoceramid genera/species.

\section{Acknowledgements}

The authors thank the Department of Geology for providing facilities of research work. One of the authors (S K) thankfully acknowledges the CSIR, New Delhi for the financial support in the form of JRF (CSIR) and SRF (RGNF, UGC). The authors are also thankful to the two anonymous reviewers for their critical comments and suggestions, which helped them considerably in enhancing the quality of the paper.

\section{References}

Acharya S K and Lahiri T C 1991 Cretaceous palaeogeography of the Indian sub-continent: A review; Cret. Res. 12 $3-26$.

Akhtar K and Khan D A 1997 A tidal island model for carbonate sedimentation: Karondia limestone of Cretaceous Narmada basin; J. Geol. Soc. India 50 481-490.

Badve R M and Ghare M A 1977 Palaeoecological aspects of the Bagh Beds: India; Rec. Res. Geol. 4 388-402.

Bardhan S, Gangopadhyay T K and Mandal U 2002 How far did India drift during the Late Cretaceous? Placenticeras kaffrarium Etheridge, 1904 (Ammonoidea) used as a measuring tape; Sedim. Geol. 147 193-217.

Biswas S K 1987 Regional tectonic framework structure and evolution of western marginal basins of India; Tectonophys. 135 307-327.

Blanford W T 1869 Geology of the area between Tapti and Narmada valley and the adjoining districts of the Malwa and Gujarat; Geol. Surv. India Memoir 6 1-222.

Bose P N 1884 Geology of the lower Narbada valley between Nimawar and Kawant; Geol. Surv. India Memoir 21 1-72.

Chiplonkar G W and Ghare M A 1976 Palaeontology of Bagh Beds - Part VII: Ammonoidea; Bull. Earth Sci. 4-5 1-10.

Chiplonkar G W, Badve R M and Ghare M A 1977 On the stratigraphy of the Bagh Beds of the lower Narbada valley; In: Proceedings of the IVth Colloquium on Indian Micropalaeontology and Stratigraphy (eds) Venkayachala B S and Sastri V V, Institute of Petroleum Exploration, Dehra Dun, 209-216.

Ion J, Antonescu E, Melinite M C and Szasz L 2004 Integrated biostratigraphy of the Turonian of Romania; Acta Palaeontol. Romaniae 4 151-161.

Jafar S A 1982 Nanoplankton evidence of Turonian transgression along Narmada Valley, India and TuronianConiacian boundary problem; J. Palaeontol. Soc. India $\mathbf{2 7}$ 17-30.
Jaitly A K and Ajane R 2013 Comments on Placenticeras mintoi (Vredenburg, 1906) from the Bagh Beds (Late Cretaceous), central India with special reference to Turonian Nodular Limestone Horizon; J. Geol. Soc. India 81 565574.

Kennedy W J and Gale A S 2016 Turonian ammonites from northwestern Aquitaine, France; Cret. Res. 58 265296.

Kennedy W J, Phansalkar V G and Walaszczyk I 2003 Prionocyclus germari (Reuss 1845), a Late Turonian marker fossil from the Bagh Beds of central India; Cret. Res. 24(4) 433-438.

Khosla A, Kapur V V, Sereno P C, Wilson J A, Wilson G P, Dutheil D, Sahni A, Singh M P, Kumar S and Rana R S 2003 First dinosaur remains from the CenomanianTuronian Nimar Sandstone (Bagh Beds), District-Dhar, Madhya Pradesh, India; J. Palaeontol. Soc. India 48 115127.

Kumar S, Singh M P and Mohabey D M 1999 Lameta and Bagh Beds, central India, Field Guide; J. Palaeontol. Soc. India, 48p.

Kundal P and Sanganwar B N 1998 Stratigraphical, palaeogeographical and palaeoenvironmental significance of fossil calcareous algae from Nimar Sandstone Formation, Bagh Group (Cenomanian-Turonian) of Pipaldehla, Jhabua, MP; Curr. Sci. 75(7) 702-703.

Nagao T and Matsumoto T 1939 A monograph of the Cretaceous Inoceramus of Japan. Part 1; J. Fac. Sci., Hokkaido Imperial University Series 4, 4(3-4) 241-299.

Racey R, Fisher J, Bailey H and Roy S K 2016 The value of fieldwork in making connections between onshore outcrops and offshore models: An example from India; In: The value of outcrop studies in reducing subsurface uncertainty and risk in hydrocarbon exploration and production (eds) Bowman M, Smyth H R, Good T R, Passey S R, Hirst J P P and Jordan C J, Geol. Soc. London, Spec. Publ. 436, https://doi.org/10.1144/SP436.9.

Smith A B 2010 The Cretaceous Bagh formation, India: A Gondwana window onto Turonian shallow water echinoid faunas; Cret. Res. 31 368-386.

Taylor P and Badve R M 1995 A new cheilostome bryzoan from the Cretaceous of India and Europe: A cyclostomes homeomorph; Palaeontology 38(3) 627-657.

Tripathi S C 2006 Geology and evolution of the Cretaceous Infratreppean basins of lower Narmada valley, western India; J. Geol. Soc. India 67 459-468.

Wilmsen M and Nagm E 2013 Upper Cenomanianlower Turonian ammonoids from the Saxonian Cretaceous (lower Elbtal Group, Saxony, Germany); Bull. Geosci. 88(3) 647-674.

Wright C W, Calloman J H and Howarth M K 1996 Treatise on invertebrate paleontology, Part L, Mollusca 4 revised (Cretaceous Ammonoidea), Geological Society of America; Boulder and University of Kansas Press, Lawrence, $362 \mathrm{p}$.

Zonova D T and Yazykova E A 1998 Biostratigraphy and correlation of the Turonian-Coniacian succession and the Turonian-Coniacian boundary problem in the Far East Russia based on ammonites and inoceramids; Acta Geol. Polonica 48(4) 483-494. 